\title{
Studies on Thiaminase of Fungi
}

\section{Thiaminase of Lentinus edodes (Berg.) Sing. ${ }^{1}$}

\author{
TAdayoshi ONo AND MASAhIRo KAWASAKI ${ }^{2}$
}

\begin{abstract}
Osaka Agricultural Research Center, Habikino, Osaka-fu (Post No. 583) and Department of Applied Chemistry, Faculty of Science and Engineering, Kinki University, Higashi Osaka, Osaka-fu(Post No. 577)
\end{abstract}

(Received October 7, 1967)

1. It was confirmed that thiaminase and thermostable factor existed in "Shiitake", Lentinus edodes (Berg.) Sing. by chemical and microbiological methods. 2. The optimum $\mathrm{pH}$ of the enzyme was 6.5 , and the optimum temperature $20^{\circ}$. It was inactivated by heating at $45^{\circ}$ for 10 minutes. Organic bases such as pyridine, aniline, quinoline and $P$-aminobenzoic acid activated the activity, as was the case with thiaminase I. Pyrichrome was produced by ferricyanide oxidation in the presence of pyridine. 3 . The thermostable factor was active at $\mathrm{pH} 6$ or above, and at $60^{\circ}$ or above. 4. The enzyme activity in the fungus was greatest in the gillus, followed by the stipe and the pileus. 5. The content of thiamine in the fungus was greatest in the gillus, followed by the pileus, and the stipe, and about $70 \%$ of the vitamin was in the esterified form.

The presence of thiaminase in the certain plants (1-7) and molds (8-12) has hitherto been studied extensively. However, there are few investigations dealing with the presence of thiaminase in fungi. It was reported that "Matsutake", Tricholima Matsutake Sing. lacked the enzyme (7). The authors have noticed the marked difference in thiamine contents between dried and fresh "Shiitake", Lentinus edodes (Berg.) Sing. and suspected the presence of the enzyme. Research on that fungus has led to the recognition of thiaminase. The properties of the enzyme are described in this paper.

\section{Materials And Methods}

\section{Materials}

L. edodes Sing. used were mostly harvested in Osaka district in spring, 1966.

2. Determination of Thiaminase

The enzyme was extracted as follows. L. edodes was extracted with water by grinding with sea sand, and centrifugation at $3,000 \mathrm{rpm}$ for 10 minutes. The

\footnotetext{
1 The outline of this report was read at the 169th Meeting of Vitamin B Research Committee (Sep. 1966) by Dr. A. Fujita.

2 小野忠義, 川崎正弘.
} 
supernatant was used as the enzyme preparation. The reaction system contained

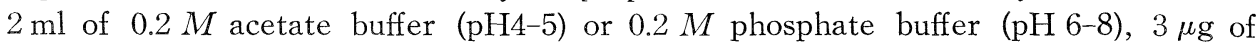
thiamine, and $1 \mathrm{ml}$ of the enzyme solution in a total volume of $4 \mathrm{ml}$. It was incubated at a certain temperature for 1 hour. Then, the enzyme was inactivated by heating at $100^{\circ}$ for 5 minutes after adjusting the $\mathrm{pH}$ to 4.5 , and the amount of residual thiamine was estimated by the thiochrome assay and microbiological assay (using Lactobacillus fermenti 36) after Takadiastase hydrolysis (14). Thiaminase potency was expressed according to Fujita (15), as the amount of thiamine degraded in $\mu \mathrm{g}$ per $\mathrm{g}$ dry matter of the sample under the optimal conditions of $\mathrm{pH}$ and temperature in 1 hour when more than 50 per cent of the thiamine added is degraded. As a control test, the enzyme solution was heated at $100^{\circ}$ for 5 minutes, and the $\mathrm{pH}$ of this reaction mixture was adjusted to 4.5 to prevent the action of thermostable factor.

\section{Determination of Thermostable Factor}

Thermostable factor was determined according to Okamoto (7). The reaction mixture contained $2 \mathrm{ml}$ of $0.2 M$ phosphate buffer $(\mathrm{pH} 7.0$ ), $1 \mathrm{ml}$ of thermostable factor solution (heated for 30 minutes at $100^{\circ}$ ) and $3 \mu \mathrm{g}$ of thiamine in a total volume of $4 \mathrm{ml}$. After incubation at $80^{\circ}$ for 1 hour, the amount of the thiamine degraded was estimated, and the thermostable factor potency was calculated.

\section{Estimation of Thiamine in Lentinus edodes}

The tissue of the fungus was heated at $100^{\circ}$ for 5 minutes, and homogenized. The extract was adjusted to $\mathrm{pH} 4.5$, Takadiastase solution was added, and the whole was incubated at $45^{\circ}$ for 2 hours. Then, the amount of thiamine remaining in the extract was estimated by thiochrome assay.

\section{Results}

\section{Detection of Thiaminase Activity by Chemical and Microbiological Methods}

The thiamine remaining in the reaction system was measured by chemical and microbiological methods, and the results shown in Table 1 were obtained. The degradation rate of thiamine was found to be 65 and $60 \%$ respectively. There was no significant difference between both values.

TABLE 1

Thiaminase Activity Determined by Microbiological and Chemical Assays

\begin{tabular}{lc}
\hline \hline Assay method & Thiamine degradation \\
\hline & per cent \\
Chemical & 65 \\
Microbiological & 60 \\
\hline
\end{tabular}

Reaction system consisted of $1 \mathrm{ml}$ of thiamine solution containing $3 \mu \mathrm{g}, 2 \mathrm{ml}$ phosphate buffer solution $(\mathrm{pH} 6.5)$ and $1 \mathrm{ml}$ of the enzyme. It was incubated at $20^{\circ}$ for $1 \mathrm{hr}$. 


\section{Properties of the Thiaminase}

Optimum $\mathrm{pH}$ - Acetate buffer ( $\mathrm{pH} 4$ to 5) and phosphate buffer ( $\mathrm{pH} 6$ to 8) were used as buffer solutions. As shown in Fig. 1, the optimum pH was 6.5.

Optimum Temperature - The effects of temperature were investigated in the range of $15-45^{\circ}$. As shown in Fig. 2, the optimum temperature was $20^{\circ}$. The activity was markedly dropped at $30^{\circ}$, and completely inactivated at $45^{\circ}$.

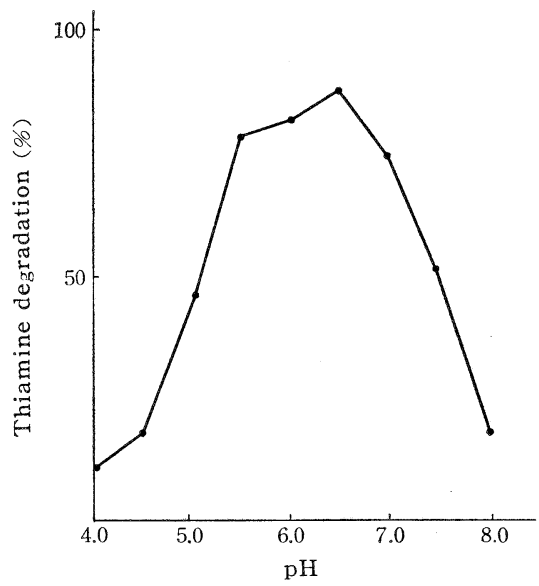

FIG. 1 Effect of $p H$ on Thiamine Degradation

Reaction system contained $1 \mathrm{ml}$ of thiamine solution $(3 \mu \mathrm{g}), 2 \mathrm{ml}$ of buffer solution and 1 $\mathrm{ml}$ of the enzyme. It was incubated at $20^{\circ}$ for $1 \mathrm{hr}$.

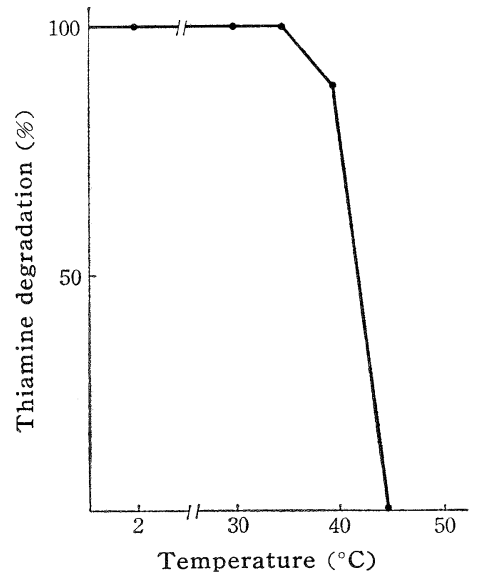

FIG. 3 Thermostability of Thiaminase

Reaction system, containing $1 \mathrm{ml}$ of the enzyme and $2 \mathrm{ml}$ of phosphate buffer (pH 6.5), was kept at varying temperatures for $10 \mathrm{~min}$.

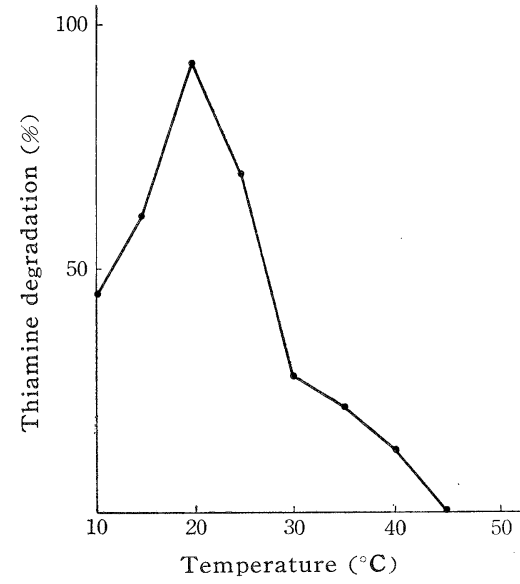

FIG. 2 Effect of Temperature on Thiamine Degradation

Reaction system contained $1 \mathrm{ml}$ of thiamine solution $(3 \mu \mathrm{g}), 2 \mathrm{ml}$ of buffer solution and 1 $\mathrm{ml}$ of the enzyme. It was incubated at different temperatures for $1 \mathrm{hr}$.

Thermostability - The thermostability of the enzyme was tested as follows. The mixture containing $2 \mathrm{ml}$ of phosphate buffer $(\mathrm{pH}$ 6.5) and $1 \mathrm{ml}$ of the enzyme solution was heated at various temperatures for 10 minutes, and the activity of the enzyme was determined. As a control test, the mixture was kept at $2^{\circ}$ for 10 minutes. As shown in Fig. 3, the enzyme was not affected between $2^{\circ}$ and $35^{\circ}$, but was inactivated at $45^{\circ} \mathrm{com}$ pletely.

Acceleration by Organic Bases- The effects of organic bases on the activity of the enzyme were investigated at $10^{-3} \mathrm{M}$ of the compound in the reaction mixture. As shown in Table 2, acceleration of the enzyme activity by organic bases such as $p$ aminobenzoic acid, quinoline, aniline and pyridine were 28, 418, 698 and 739 per cent 
TABLE 2

Effect of Several Organic Bases

\begin{tabular}{lc}
\hline \hline Substance $\left(10^{-3} M\right)$ & Acceleration rate \\
\hline & per cent \\
Pyridine & 739 \\
Aniline & 698 \\
Quinoline & 418 \\
$p$-Aminobenzoic acid & 28 \\
\hline
\end{tabular}

respectively. When the ferricyanide oxidation method was used in the case of pyridine, pyrichrome was produced (16-17), whereas it failed to be produced when the cyanogen bromide oxidation method was used.

\section{Determination of Thermostable Factor}

Not only thiaminase but also thermostable factor was proved to exist in $L$. edodes. The factor remained active after heating at $100^{\circ}$ for 30 minutes. The results of the experiments of the factor on the effects of $\mathrm{pH}$ and temperature are shown in Figs. 4 and 5. The activity was undetected at $\mathrm{pH} \mathrm{6.0,} \mathrm{but} \mathrm{it} \mathrm{was} \mathrm{distinct}$ at $\mathrm{pH}$ 7.0. On the other hand, at the temperature under $40^{\circ}$ no activity was observed, but it rose markedly above $60^{\circ}$.

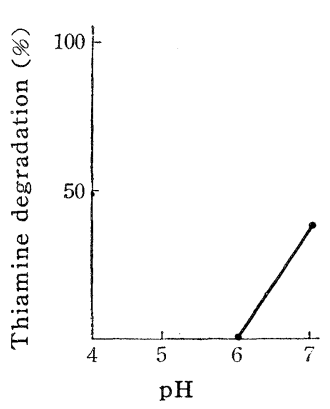

FIG. 4 Effect of $p H$ on Thermostable Factor Activity

Reaction system, containing $1 \mathrm{ml}$ of thiamine solution $(3 \mu \mathrm{g}), 2 \mathrm{ml}$ of different buffer solution and $1 \mathrm{ml}$ of the thermostable factor solution, was incubated at $80^{\circ}$ for $1 \mathrm{hr}$.

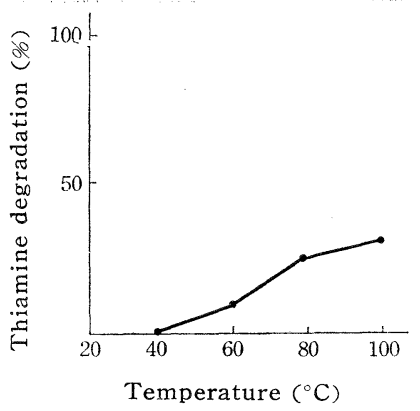

FIG. 5 Effect of Temperature on Thermostable Factor Activity

Reaction system, containing $1 \mathrm{ml}$ of thiamine solution $(3 \mu \mathrm{g}), 2 \mathrm{ml}$ of buffer solution and 1 $\mathrm{ml}$ of the thermostable factor solution, was incubated at $80^{\circ}$ for $1 \mathrm{hr}$.

\section{Test for Thiamine Disulfide}

According to Tamaki (18), $2 \mathrm{ml}$ of phosphate buffer (pH 7.0), $1 \mathrm{ml}$ of thiamine solution $(3 \mu \mathrm{g})$ and $1 \mathrm{ml}$ of cysteine $(100 \mathrm{mg} / 100 \mathrm{ml})$ were added to $1 \mathrm{ml}$ of the enzyme solution, the mixture was incubated at $37^{\circ}$ for 1 hour, and the amount of remaining thiamine was determined. The result failed to show the conversion into thiamine disulfide.

\section{Change of Thiaminase Potency and Thiamine Content in Various Seasons}

The thiaminase potencies of the commercial fresh fungi in various seasons were estimated as described above $\left(\mathrm{pH} 6.5,20^{\circ}, 1 \mathrm{hr}\right)$. As shown in Table 3, the potency and thiamine content of each fungus showed remarkable fluctuation and no definite dependency upon seasons could be detected. 
TABLE 3

Thiaminase Activity of the Commercial Fungus in Various Seasons

\begin{tabular}{llc}
\hline Month & Thiaminase potency & \multicolumn{1}{c}{ Thiamine content } \\
\hline & & $\mu g / 100 g$ fresh weight \\
January & & $86.4 ; 148.0 ; 62.9 ; 115.7$ \\
February & $50.0 ; 88.1 ; 77.4 ; 93.5 ; 54.2 ; 38.4$ \\
March & $94.9 ; 75.8 ; 116.3 ; 66.7 ; 39.3$ \\
April & $19.6 ; 12.0$ \\
May & $12.8 ; 13.2 ; 20.7$ \\
June & 24,$7 ; 22.5 ; 11.9 ; 9.9$ & $56.0 ; 87.4 ; 74.5$ \\
July & 6.0 & \\
September & 2.8 & \\
October & $10.3^{a} ; 14.5^{b}$ & \\
November & 25.1 & $81.7 ; 69.3$ \\
December & $20.5 ; 11.9$ & $115.0 ; 158.6$ \\
\hline
\end{tabular}

$a$ Produced in Okayama. $\quad b$ Produced in Nara.

6. Thiaminase Potencies and Thiamine Contents in Various Parts of the Fungus

The various parts, pileus, gillus and stipe (Fig.6), were used for testing the thiaminase potency and thiamine content and the results shown in Table 4 were obtained. Thiaminase was found strongest in the gillus, followed by the stipe and the pileus, and about 70 per cent of the vitamin was in the esterified form (Table

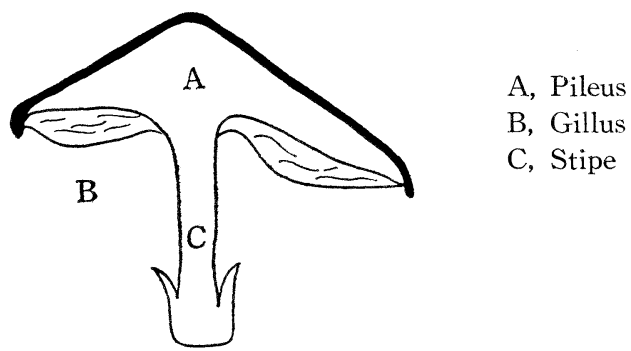

FIG. 6 Fruit Body of Lentinus edodes Sing.

TABLE 4

Thiaminase Potency in Various Parts of L. edodes

\begin{tabular}{|c|c|c|c|}
\hline Part & & Thiaminase potency & Thiamine content \\
\hline $\begin{array}{l}\text { Pileus } \\
\text { Gillus } \\
\text { Stipe }\end{array}$ & & $\begin{array}{l}7.4 ; 2.0 \\
22.5 ; 6.0 \\
13.7 ; 3.7\end{array}$ & $\mu g / 100 g$ fresh weight \\
\hline Pileus & $\begin{array}{l}\text { Large }^{a} \\
\text { Middle }^{b} \\
\text { Small }^{c}\end{array}$ & $\begin{array}{l}23.8 \\
24.7 \\
26.1\end{array}$ & $\begin{array}{l}147 \\
145 \\
208\end{array}$ \\
\hline $\begin{array}{l}\text { Edible } \\
\text { Parts }\end{array}$ & $\begin{array}{l}\text { Large } \\
\text { Middle } \\
\text { Small }\end{array}$ & & $\begin{array}{r}78.0 \\
74.5 \\
113.7\end{array}$ \\
\hline
\end{tabular}

$a$ Diameter of pileus $8.0 \mathrm{~cm}$

${ }^{b}$ Diameter of pileus $5.5 \mathrm{~cm}$

c Diameter of pileus $4.0 \mathrm{~cm}$ 
TABLE 5

Thiamine Content in Various Parts of L. edodes

\begin{tabular}{lcccc}
\hline \multirow{2}{*}{ Thiamine } & \multicolumn{3}{c}{ Thiamine content } & \multirow{2}{*}{ Total fungus } \\
\cline { 2 - 3 } & Pileus & Gillus & Stipe & \\
\hline & & $\mu g / 100 \mathrm{~g}$ & $\mu \mathrm{g} / 100 \mathrm{~g}$ \\
Free & 21.8 & 34.2 & 12.5 & 22.8 \\
Ester & 40.4 & 104.5 & 40.3 & 61.8 \\
Total & 62.2 & 138.7 & 52.8 & 84.6 \\
Ester/total $1 \%)$ & 65 & 75 & 76 & 72 \\
\hline
\end{tabular}

5). In the estimation of thiamine in the fungus the presence of thiaminase has hitherto not been taken into consideration. The authors have measured the thiamine content after inactivation of the enzyme. The thiamine contents seemed to be higher in smaller fungi (Table 4). The thiamine contents in commercial dried fungi obtained in May were as follows $(\mu \mathrm{g} / 100 \mathrm{~g}): 56.0$ (Osaka); 133.3 (Kyushu); 247.4* (Kiryu, W No. 121); 203.5* (Kiryu, W No. 4). (*dried by an infrared lamp). The individual variation was so marked

\section{Loss of Thiamine in the Fungus by Dehydration}

To test the loss of thiamine by heat-dehydration of the fungi, one part of the fresh fungus was dried by heat and the other part of the same fresh fungus was used without drying for estimating the thiamine content. As given in Table 6, the contents of the vitamin were almost the same, when calculated on the fresh weight basis, showing that the vitamin was scarcely lost by drying by heat.

TABLE 6

Thiamine Contents of Heat-dried Preparation Prepared from Fresh Fungi

\begin{tabular}{cccc}
\hline & \multicolumn{3}{c}{$\begin{array}{c}\text { Thiamine contents } \\
\text { (Calculated as } \mu g / 100 \mathrm{~g} \text { fresh weight) }\end{array}$} \\
\hline Fresh & 88.1 & 77.4 & 93.5 \\
Dried & 85.4 & 72.1 & 88.1 \\
\hline
\end{tabular}

\section{Thiamine Degradation by Tissue Destruction}

A part of the raw fungus was sliced along the gillus, 3 or $0.1 \mathrm{~cm}$ thick, and another part was ground with water together with sea sand in a glass mortar. They were allowed to stand separately at $20^{\circ}$ for 1 hour. After inactivating the enzyme, the vitamin was estimated. The thiamine contents given in Table 7 show that the thiamine in the slice, $3 \mathrm{~cm}$ thick, was not affected, that in the slice, $0.1 \mathrm{~cm}$ thick, was somewhat degraded and that in the ground tissue was degraded by more than half.

TABLE 7

Destractive Effect of Fruit Body Treatment on Thiamine Content

\begin{tabular}{lc}
\hline \hline & Thiamine content \\
\hline & $\mu g / 100 \mathrm{~g}$ \\
Control & 148 \\
Slice, 3 cm thick & 150 \\
Slice, 0.1 cm thick & 141 \\
Homogenate & 55 \\
\hline
\end{tabular}




\section{Discussion}

Thiamine contents of fresh and dried L. edodes given in the Standard Table of Food Composition of Japan (13) are 640 and $320 \mu \mathrm{g}$ per $100 \mathrm{~g}$ respectively. Comparing the calculated values of thiamine on the dry matter basis, the dried fungus contained the vitamin about $1 / 20$ of the fresh one (Table 8). It suggested the existence of thiaminase in the fungus, and the experiment has proved the assumption. The optimum temperature of the enzyme was $20^{\circ}$, corresponding to the optimum growth temperature of the fungus and the optimum $\mathrm{pH} 6.5$, corresponding to the $\mathrm{pH}$ of the fungus tissue. Furthermore, the enzyme is concentrated in the gillus, where the spores of the fungus are localized, and in this part, most thiamine was found to exist. These findings seem to be of biological interest.

The thiaminases, which have been found thus far, are active at $30^{\circ}$ to $60^{\circ}$, and are inactivated by heating at $90-100^{\circ}$ for $10-20$ minutes. However, the thiaminase of L. edodes have an optimum temperature of $20^{\circ}$ and inactivated by heating at $45^{\circ}$ for 10 minutes, a finding characteristic of this enzyme. The molds producing thiaminase were investigated by Jacobson (8), Ozawa et al. (10) and Ikehata (12). They were all reported to belong to thiaminase II, whereas the enzyme in $L$. edodes was found to be thiaminase I. The enzyme activity in $L$. edodes hypha and fruit body is being investigated.

Comparison of the thiamine contents of the fungus between sliced and ground one after incubation at the optimum temperature of the enzyme for 1 hour, showed that the values of the sliced ones did not change significantly, whereas the value of the ground one was decreased markedly to about one half. It is therefore considered that the thiamine in the fungus is not significantly degraded by cutting in ordinary cooking.

In the reports related to thiamine contents of $L$. edodes, Chin (19) and Takahashi (20) showed that a trace amount of thiamine is contained in the fresh fungus. In the dried fungus, Sumi (21) concluded from animal experiment that it contained scarcely any thiamine, Miyayoshi et al. (22) also reported the same results. However, Haraki (23) reported that the thiamine content in the dried L.edodes pileus was $129 \mu \mathrm{g}$ per $100 \mathrm{~g}$ dry matter. The Standard Table of Food Composition of Japan (13) gives the values of thiamine in fresh and dried L. edodes, 640 and $320 \mu \mathrm{g}$ per $100 \mathrm{~g}$ respectively, and "Vitaminology" (24) gives the value of $500 \mu \mathrm{g}$

TABLE 8

Thiamine Contents in Fresh and Dried Fungus

\begin{tabular}{|c|c|c|}
\hline & \multicolumn{2}{|c|}{ Content of thiamine } \\
\hline & In fresh weight & In dry weight \\
\hline & \multicolumn{2}{|c|}{$\mu g / 100 g$} \\
\hline Fresh fungus & 100 & $1,145^{b}$ \\
\hline Fresh fungus & $640^{a}$ & $7,800^{c}$ \\
\hline Dried fungus & $320^{a}$ & $380^{c}$ \\
\hline
\end{tabular}

a Values in the Standard Table of Food Composition of Japan (1963).

$b$ The value found by the authors.

$c$ Calculated from water content. 
per $100 \mathrm{~g}$ dry matter. Thus, the thiamine contents fluctuate markedly. It is partly due to the determination of the vitamin, without the existence of thiaminase being taken into consideration.

\section{ACKNOWLEDGEMENT}

The authors wish to thank Professor Akiji Fujita, Women's College of Nutrition, for helpful directions.

\section{REFERENCES}

1. Wesing, P. H., Freed, A. M., and Haag, J.R., J. Biol. Chem., 165. 737 (1946).

2. Miura, U., Fujihara, M., and Matsui, K., Vitamins, 3, 230 (1950).

3. Fujita, A., and Numata, I., Seikagaku, 18, 339 (1944).

4. Fujiwara, M., and Matsui, K., J. Biochem., 40, 427 (1953).

5. Fujita, A., Nose, Y., and Okamoto, T., Vitamins, 4, 138 (1951).

6. Fujita, A., and Okamoto, T., Vitamins, 4, 381 (1951).

7. Okamoto, T., Vitamins, 6, 26, 30 (1953).

8. Kurt, P., Jacobsohn, and Yose, M., Compt. rend. Soc. Biol., 146, 1454 (1952).

9. Kurt, P., and Deodata de Ageveel, M., Comp. rend. Soc. Biol., 146, 1456 (1952).

10. Ozawa, K., Nakayama, H., and Hayashi, R., J. Vitaminol., 3, 282 (1957).

11. Yoshioka, T., Vitamins, 14, 188 (1958).

12. Ikehata, H., and Saji, Y., Vitamins, 16, 56 (1959).

13. Kagaku Gijutsucho Shigenkyoku, Standard Table of Food Composition of Japan (1963).

14. Macias, R. F.M., Appl. Microbiol., 5, 249 (1957).

15. Fujita, A., Method of Vitamin Assay (Japanese), p. 248, Nankodo (1955).

16. Fujita, A., Nose, Y., and Hasegawa, E., J. Biol. Chem., 196, 297 (1952).

17. Nose, Y., Seikagaku, 24, 25 (1952).

18. Tamaki, T., and Nose. T., J. Vitaminol., 1, 85 (1955).

19. Chin, T., Peiping Nutrition Report, 3, 11 (1936).

20. Takahashi, S., Eiyo to Shokuryo, 8, 25 (1955).

21. Sumi, M., Riken Ho., 7, 10 (1928) : 8, 3 (1929): 11, 20 (1932) : 17, 1296 (1938).

22. Miyayoshi, H., and Kawakami, Y., Nippon Nogei Kagaku, 16, 1098 (1940).

23. Haraki, T., Seikagaku, 18, 468 (1946).

24. Sabashi, K., Vitaminology (Japanese), p. 727, Kanehara Shuppan, Tokyo (1956). 